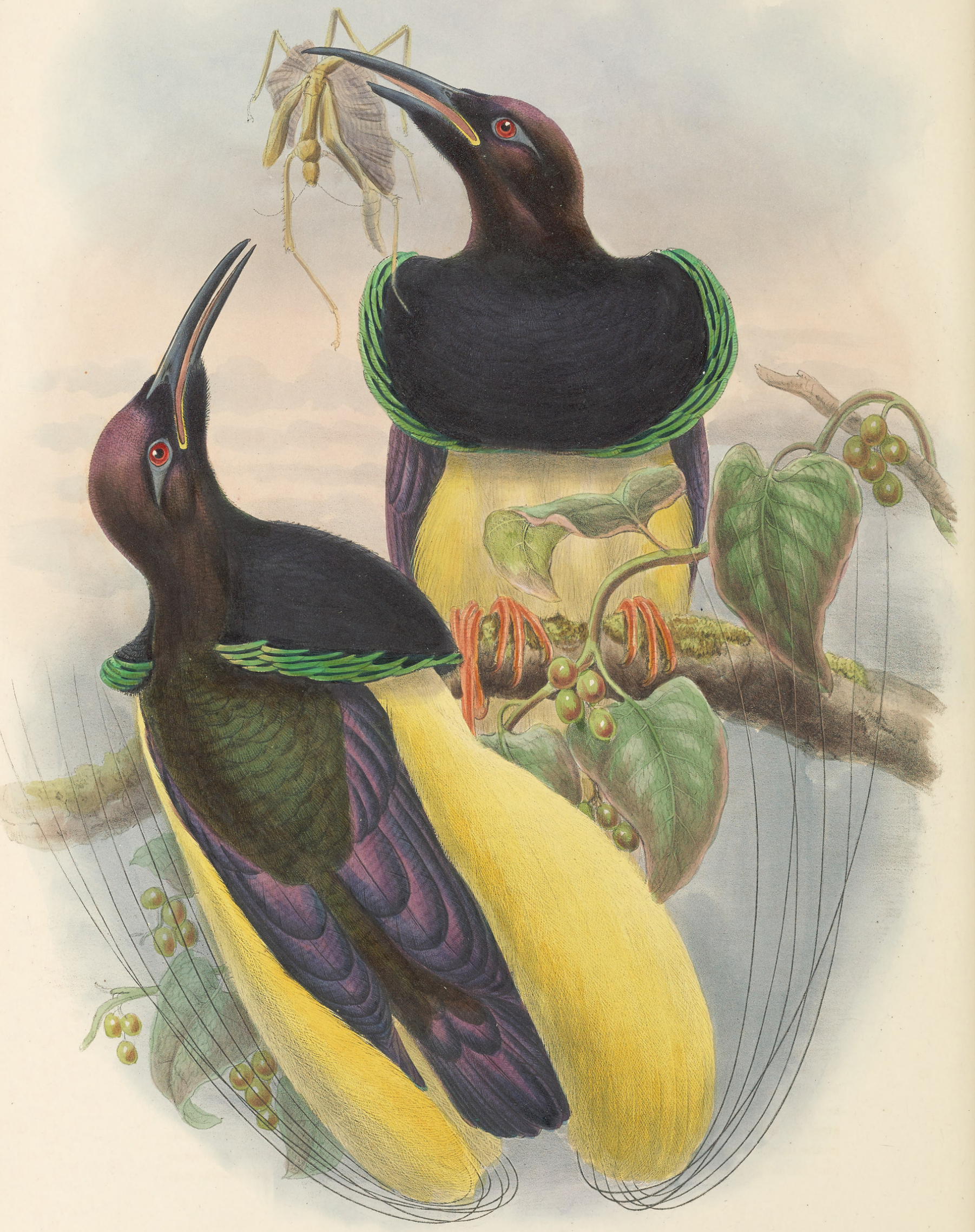




\section{SELEUCIDES NIGRICANS.}

\section{Twelve-wired Bird of Paradise.}

Le Manucode à douze filets, Audeb. et Vieill. Ois. Dor. ii. p. 29, pl. 13.

Le Nébuleux, Levaill. Ois. de Parad. i. pls. 16, 17.

Le Promerops multifil, Levaill. H. N. Promer. et Guêp. pl. 17.

Paradisea nigricans, Shaw, Gen. Zool. vii. pt. 2, p. 489 (1809).

alba, Blumenb. Abbild. nat. Gegenst. pl. 96.-Schleg. J. f. O. 1861, p. 386.

resplendescens, Vieill. Nouv. Dict. xxviii. p. 165.-Id. Galerie Ois. p. 107, pl. 185.

Epimachus albus, Temm. Man. d’Orn. i. p. lxxxvi.-Wagl. Syst. Av. 1827, Epimachus, sp. 9.-Gray, Gen. B. ii. p. 94.-Id. P. Z. S. 1858 , p. 190.-Id. List B. New Guinea, pp. 21, 55.-Id. P. Z. S. 1861, p. 433.Wallace, P. Z. S. 1862, p. 160.-Schleg. Mus. P.-B., Coraces, p. 95.-Id. Nederl. Tijdschr. Dierk. iv. p. 49.-Gray, Hand-1. B. i. p. 105.

Twelve-wired Paradise Bird, Lath. Gen. Hist. iii. p. 199, pl. 48.

Seleucides acanthylis, Less. H. N. Ois. Parad. pls. 36-38.-Id. Syn. p. 29.

Nematophora alba, Gray, List Gen. B. i. p. 12.

Seleucides alba, Gray, List Gen. B., Addenda, p. 1.-Bp. Consp. i. p. 412.-Cab. Mus. Hein. i. p. 215.-Reichenb. Handb. Spec. Orn. Scansoriæ, p. 331, taf. 612, figs. 4092, 4093.-Wallace, Malay Archip. ii. p. 250.Elliot, Monogr. Parad. pl. xxii.-Salvad. Ann. Mus. Civ. Genova, vii. p. 785.-Beccari, t. c. p. 7 13.Scl. P. Z. S. 1876, p. 252.

Ptiloris nebulosus, Licht. Nomencl. p. 10.

Seleucides resplendens, Rosenb. Nat. Tijdschr. Nederl. Ind. xxv. p. 238._Id. J. f. O. 1864, p. 123.

Epimachus resplendens, Rosenb. Reist. naar Geelvinkb. pp. 101, 116.

Seleucides ignota, Salvad. Ann. Mus. Civ. Genova, viii. p. 403; ix. p. 191 ; x. p. 154.-D'Albert. \& Salvad. op. cit. xiv. p. 107. niger, Sharpe, Cat. B. iii. p. 159.

Epimachus resplendescens, Rosenb. Malay Arch. p. 552.

Seleucides nigricans, Salvad. Orn. della Papuasia \&c. p. 561 (1881).

THE list of names given above shows that this species of Bird of Paradise has been known to writers for a long period. Most of the synonymy I have derived from Mr. Bowdler Sharpe's 'Catalogue of Birds,' and from the more complete list of works given by Count Salvadori in his recently published book on the birds of New Guinea. When I state that I have by no means exhausted the synonymy of the species as set down by Count Salvadori, it may readily be imagined that the number of books in which reference is made to the species is very large indeed. I have not, however, full space for such lengthened synonymy in the present work, and must refer the reader to the above-mentioned volumes for further quotations. The Twelve-wired Bird of Paradise is the only representative of the genus Seleucides, which belongs to the slender-billed section of the Paradiseidæ. It is remarkable for its elongated flank-feathers, which are of a fine yellow colour, and have six shafts produced into thread-like plumes, whence the bird has received its ordinary English name. Unfortunately the beautiful yellow colour on the flanks fades away after death, and becomes white, when the bird loses much of its original beauty.

With regard to the nomenclature of the bird, I have come to the conclusion that the first name, which ought to be employed, is that of nigricans of Shaw, as has been set forth by Count Salvadori. As far as we know at present, it is entirely confined to New Guinea, over the whole of which great island it appears to be distributed. It is abundant on the Fly river, to judge by the large series obtained by Signor D'Albertis during his residence in Southern New Guinea. He found it living solitary, and frequently resting on the dead branch of a tree, uttering its note (which sounded like Có-có-có) in the early morning at the rising of the sun ; during the day it was silent. Mr. Wallace, in his 'Malay Archipelago,' gives the following account of the species:- "The Seleucides alba is found in the island of Salwatty, and in the north-western parts of New Guinea, where it frequents flowering trees, especially sago-palms and pandani, sucking the flowers, round and beneath which its unusually large and powerful feet enable it to 
cling. Its motions are very rapid. It seldom rests more than a few moments on one tree, after which it flies straight off, and with great swiftness, to another. It has a loud shrill cry, to be heard a long way, consisting of 'cáh, cáh,' repeated five or six times in a descending scale; and at the last note it generally flies away. The males are quite solitary in their habits, although, perhaps, they assemble at certain times like the true Paradise-birds. All the specimens shot and opened by my assistant Mr. Allen, who obtained this fine bird during his last voyage to New Guinea, had nothing in their stomachs but a brown sweet liquid, probably the nectar of the flowers on which they had been feeding. They certainly, however, eat both fruit and insects; for a specimen, which I saw alive on board a Dutch steamer, ate cockroaches and paya fruit voraciously. This bird had the curious habit of resting at noon with the bill pointing vertically upwards. It died on the passage to Batavia; and I secured the body and formed a skeleton, which shows indisputably that it is really a Bird of Paradise. The tongue is very long and extensible, but flat, and a little fibrous at the end, exactly like the true Paradiseas.

"In the island of Salwatty the natives search in the forests till they find the sleeping-place of this bird, which they know by seeing its dung upon the ground. It is generally in a low bushy tree. At night they climb up the tree, and either shoot the birds with blunt arrows, or even catch them alive with a cloth. In New Guinea they are caught by placing snares on the trees frequented by them, in the same way as the Red Paradise-birds are caught in Waigiou."

Only on one occasion has the present species been known to have been brought alive to Europe, a single example having been procured by Signor G. E. Serruti in New Guinea, and presented by him to the late King of Italy. It survived, however, only a few months in Europe.

I take the following descriptions from Mr. Sharpe's 'Catalogue of Birds ':-

Adult male. General colour above velvety black, with a strong gloss of oil-green when viewed from the light, with coppery bronze reflections; scapulars and wing-coverts resembling the back; greater coverts and secondaries fiery purple, the primaries black, with an external gloss of violet; tail fiery purple; head all round of a velvety texture, coppery purple above, oily green on the sides of the face and throat; fore neck and chest velvety black, forming a shield, somewhat shaded with oily green in the centre, the lateral plumes all tipped with bright metallic emerald-green, forming a fringe ; rest of the under surface of body buffy yellow, the plumes of the flanks elongated and silky, and furnished with six thread-like shafts, produced to a great length, and curved backwards on the body; under wing-coverts black; bill black. Total length 12 inches, culmen $2 \cdot 7$, wing $6 \cdot 45$, tail $3 \cdot 15$, tarsus 1.75 ; threads reaching $10 \cdot 2$ inches beyond the flank-feathers.

Adult female.-General colour above bright chestnut-red; back of the neck and sides of the same black; the feathers of the mantle also mottled with black, the bases of the feathers being of this colour ; crown of head and nape velvety black, with a purplish gloss when seen away from the light; wing-coverts and secondaries chestnut-red, like the back, the primaries black, chestnut on their outer webs; tail uniform chestnut; space around and behind the eye bare, as also a spot on the auricular region; ear-coverts black; sides of face and throat greyish white, faintly mottled with dusky bars of blackish; rest of under surface of body buffy brown, washed here and there with pale rufous, the whole transversely barred with somewhat irregular cross lines of blackish brown, broader on the fore neck and breast, and more faintly indicated on the abdomen, and especially on the long flank-feathers and under tail-coverts ; under wingcoverts bright chestnut, with dusky blackish cross bars. Total leugth 12.5 inches, culmen 2.55 , wing 6.5 , tail $4 \cdot 3$, tarsus $1 \cdot 7$.

Young male.-At first resembles the adult female. A specimen collected by Mr. Wallace is in perfect plumage as regards its head, mantle, and breast, the rest of the body being in the chestnut plumage of the female, the tail being still entirely chestnut. At the same time the beautiful purple colour is being put on the wings by a gradual change of feather, and not by a moult; half the inner secondaries are chestnut, but more or less mottled with black, the purple colour appearing very plainly on the inner webs.

The first Plate represents the male bird, of the natural size; and I have thought it necessary to give a second illustration of this species, in order to show some of the changes of plumage. The second Plate represents a female and a young male in its first plumage, together with another bird, of the same sex, commencing to put on his adult livery. 
He
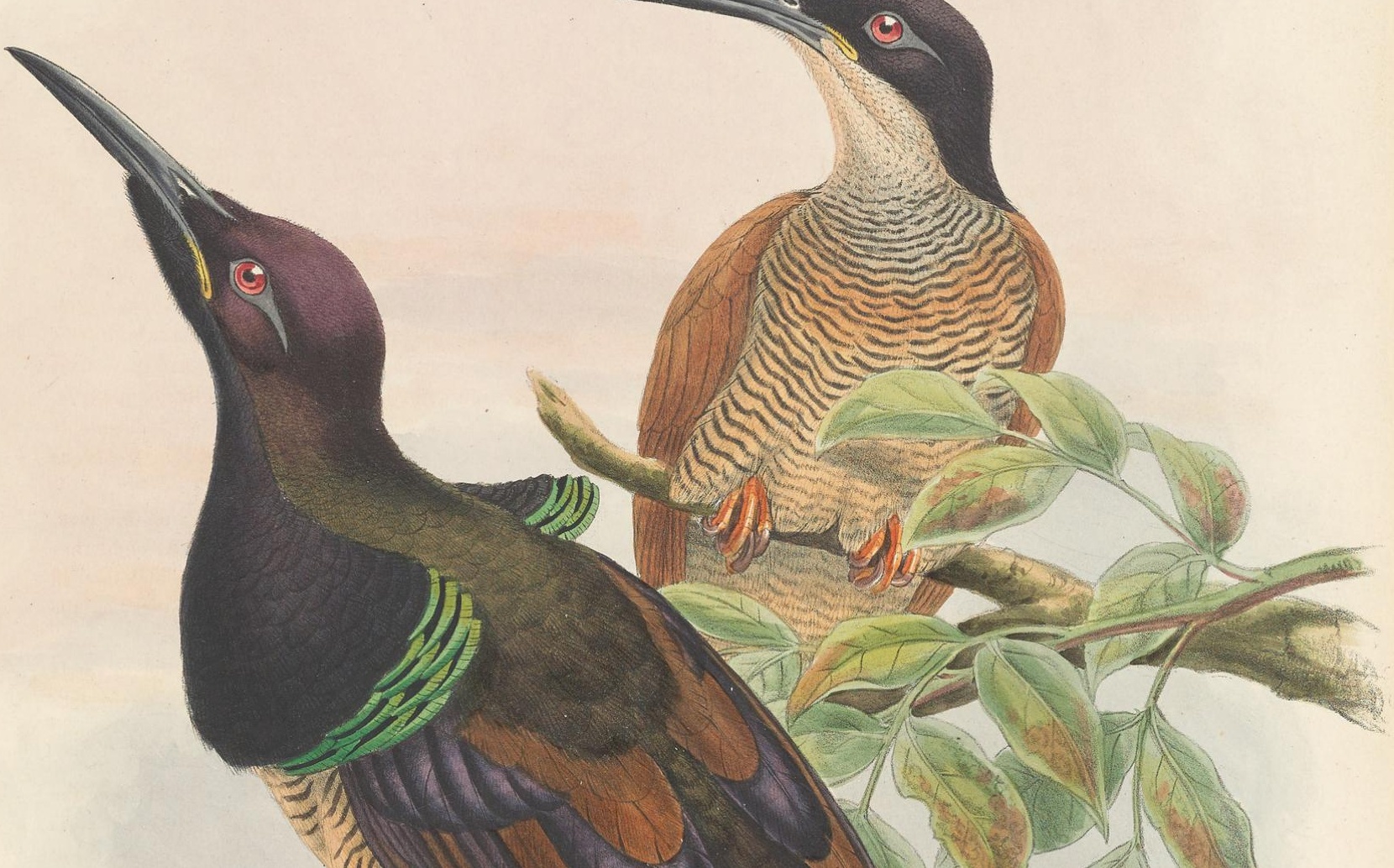


\section{$2 \mathrm{BHL}$ Biodiversity Heritage Library}

Gould, John and Sharpe, Richard Bowdler. 1881. "Seleucides nigricans, Twelve-wired Bird of Paradise [PI. 14-15]." The birds of New Guinea and the adjacent Papuan islands : including many new species recently discovered in Australia 1(XII), -. https://doi.org/10.5962/p.322615.

View This Item Online: https://www.biodiversitylibrary.org/item/229855

DOI: https://doi.org/10.5962/p.322615

Permalink: https://www.biodiversitylibrary.org/partpdf/322615

\section{Holding Institution}

Smithsonian Libraries

\section{Sponsored by}

Biodiversity Heritage Library

\section{Copyright \& Reuse}

Copyright Status: Public domain. The BHL considers that this work is no longer under copyright protection.

This document was created from content at the Biodiversity Heritage Library, the world's largest open access digital library for biodiversity literature and archives. Visit BHL at https://www.biodiversitylibrary.org. 